ROCZNIKI PEDAGOGICZNE

Tom 11(47), numer specjalny - 2019

DOI: http://dx.doi.org/10.18290/rped.2019.11s-5

JAGODA ANTONIAK

\title{
NIEDOSTOSOWANIE SPOŁECZNE NIELETNICH - PRZYCZYNY, SKUTKI, PROFILAKTYKA
}

\section{WPROWADZENIE}

Współczesny świat generuje wiele czynników powodujących nieustanne zmiany. Brak poczucia bezpieczeństwa oraz ustawiczny, narastający proces dezorganizacji społecznej, ekonomicznej i gospodarczej sprzyja destrukcji relacji międzyludzkich, tożsamości kulturowej czy chociażby modyfikuje funkcje i role społeczne. Proces destabilizacji jest elementem funkcjonowania jednostki w obecnej rzeczywistości. W celu przetrwania i próby zachowania stabilizacji konieczne jest zaakceptowanie zjawiska zmiany. Zmiana ta wiąże się z obszarami ekonomicznymi, społecznymi, gospodarczymi, jest ona zauważalna w środowisku rodzinnym; szczególnie brak stabilizacji lub trudność w jej utrzymaniu wpływa na dzieci i młodzież. Zmiany są dostrzegalne w mediach, środkach komunikacji społecznej, napływie informacji, postępie technologicznym, odzieżowym, w zakresie infrastruktury. Funkcjonowanie w globalnym systemie ciągłej zmiany i pogoni za zaspokajaniem coraz to nowych potrzeb nie sprzyja powstawaniu uformowanej, samodzielnej osobowości. Ważne jest wypracowywanie prawidłowych umiejętności odnajdywania się w zastanej rzeczywistości oraz postrzegania jej przez pryzmat nabytych pozytywnych doświadczeń. Rozumienie i analiza zjawiska zmiany sprzyja powstawaniu badań z tego zakresu, dzięki czemu powstają nowe rozwiązania skupiające się na tym, w jaki sposób przygotowywać ludzi młodych do zastanej rzeczywistości, które umiejętności są niezbędne, aby czynić to skutecznie.

Mgr JaGOda AntoniaK - doktorantka Katedry Dydaktyki i Edukacji Szkolnej, Instytut Pedagogiki, Wydział Nauk Społecznych, Katolicki Uniwersytet Lubelski Jana Pawła II; e-mail: antoniak.jagoda@gmail.com; ORCID: 0000-0002-9941-8479 
Wśród tendencji nieustannych zmian, napięć i szybkości postępujących zmiennych kluczową sprawnością wydaje się przystosowanie do zastanej rzeczywistości poprzez umiejętność wyboru. Szeroka gama ofert i możliwości przyczynia się do natłoku informacji i generacji wielu opcji wyboru. W celu prawidłowego funkcjonowania jednostka musi przyjąć i zaakceptować zaistniałe zjawisko zmiany, które jest niezależne od postępowania człowieka. Podejmowanie decyzji wiąże się ze znajomością siebie oraz umiejętnością rozgraniczenia istotnych i ważnych dla jednostki wartości. Fundamentalne znaczenie przy podejmowaniu decyzji mają wartości, stanowią one podstawę funkcjonowania człowieka i wskazują kierunek jego rozwoju. Podczas podejmowania decyzji uwidacznia się struktura i uszeregowanie tych wartości, które zajmują u danej osoby najważniejsze miejsce, inne zaś dla danej osoby są nieistotne i te znajdują się na ostatnim miejscu. Zachowanie każdego człowieka jest zależne od systemu i hierarchii wartości. W aksjologii wyróżnia się cztery podstawowe i obiektywne wartości, takie jak prawda, dobro, piękno i świętość. Inny zauważalny, bardziej powszechny podział to rozróżnienie wartości na pozytywne oraz negatywne. Do wartości pozytywnych można zaliczyć prawdę, dobro, piękno, i wiele innych, zaś wartości negatywne to te, które mają w swojej podstawie jakiś niedostatek lub brak, np. z zakresu sfery uczuciowej czy moralnej (Chudy, 2009). Człowiek w wyborze określonej danej wartości jest wolny, podejmując decyzje, wybiera daną wartość, uznając ją za ważną, za swoją. Możliwe jest oddziaływanie poprzez środowisko czy zbiorowość na podejmowanie decyzji przez danego człowieka. Jednak pomimo przebywania w danej społeczności i oddziaływania wpływów kulturowych, wybór człowieka zawsze jest jego decyzją, gdyż postępowanie to zmienia jego życie oraz przemienia innych. Każda podjęta decyzja powstaje na bazie uznanych przez jednostkę wartości, której konsekwencje ponosi on sam, jak i inni ludzie przynależący do danej grupy społecznej. Skutki danej decyzji uwidaczniają się w życiu jednostki i społeczności, w której żyje. Istotne jest, aby młody człowiek kierował się w swoim życiu wartościami obiektywnymi, służącymi jemu samemu oraz zbiorowości, którą tworzy i z którą się utożsamia (Chudy, 2009).

Niedostosowanie społeczne jest wynikiem wielu czynników i zmiennych charakterystycznych dla młodego człowieka żyjącego w danym środowisku, ukształtowanym przez dane pokolenie. Współczesny młody człowiek wychowuje się i kształci w otaczającej rzeczywistości ciągłych zmian. Jego przestrzeń jest przesiąknięta możliwościami i umiejętnością odnalezienia się w tej rzeczywistości poprzez podejmowanie decyzji. Pedagogika resocjalizacyjna zauważa wśród młodych osób pewne niekorzystne zmienne, a mianowicie młodzi stają 
się osobami odpowiedzialnymi za przestępstwa dotychczas popełniane przez dorosłych (Stańkowski, 2018). Obserwuje się wzrost zachowań przestępczych wśród młodzieży, jednocześnie niepokoi fakt, iż podejmowane działania resocjalizacyjne nie przynoszą rezultatów, gdyż większość z osób młodych popełniających przestępstwa ponownie podejmuje czyny karalne w dorosłości (Stańkowski, 2018).

\section{DEFINICJE NIEDOSTOSOWANIA SPOŁECZNEGO}

W celu zrozumienia pojęcia niedostosowania społecznego konieczne jest przytoczenie definicji, przyczyn, objawów, skutków i profilaktyki wspomnianego zjawiska. Niedostosowanie społeczne jest terminem szerokim, dostępne w literaturze przedmiotu definicje ugruntowały się na płaszczyznach socjologii, psychologii i pedagogiki. Prezentowane definicje zawierają istotne informacje, niezbędne do weryfikacji zjawiska niedostosowania społecznego oraz umiejętności zapobiegania narastającemu procesowi powstawania zachowań ryzykownych. Pojęcie niedostosowania społecznego dzieci i młodzieży wprowadziła i upowszechniła w polskiej literaturze przedmiotu pionierka z zakresu pedagogiki specjalnej - Maria Grzegorzewska. Termin „młodzież niedostosowana", wprowadzony przez Światowy Związek Instytucji Opieki nad Dziećmi i Młodzieżą we Francji, został wyjaśniony jako

zespół wszystkich nieletnich wymagających specjalnych metod wychowawczych, medyko-psychologicznych i medycznych, tych wszystkich, wobec których z jednej strony pracodawca i urzędy publiczne, muszą zastosować metody specjalne, z drugiej zaś strony wychowawcy muszą się uciekać do sposobów specjalnych; tych wszystkich, dla których trzeba czegoś innego niż dla zespołu innych (Pospiszyl, 1978, s. 15-16).

Pierwsze próby definiowania niedostosowania społecznego okazują się nie w pełni satysfakcjonujące. Prezentowana przez Światowy Związek Instytucji Opieki nad Dziećmi i Młodzieżą definicja przedstawia osoby niedostosowane społecznie jako te, które są niepełnosprawne, potrzebują pomocy i konieczne względem nich jest traktowanie specjalne. W wyniku postępu badań i ewaluacji procesu definicyjnego niedostosowania społecznego M. Grzegorzewska wprowadza zmianę znaczenia wspomnianego pojęcia przez dodanie zapisu:

Tendencje społecznie negatywne. Odwrócenie zainteresowań od wartości pozytywnych i chęć wyżycia się w akcji społecznie destruktywnej. Podziw i zainteresowanie 
dla tzw. złych czynów. Cynizm i brawura w tym względzie. Nieżyczliwy stosunek do człowieka, do cudzego mienia, regulaminów, norm i zarządzeń, nieodpowiedni stosunek do czynów własnych. Nieumiejętność zżycia się z grupą. Wyłamywanie się, zrzucanie winy. Niechęć do pracy i nauki. Brak poczucia odpowiedzialności za swoje czyny. Życie chwilą, przygodą, awanturą. Wyobraźnia duża. Brak hamulców krytycyzmu. Sugestywność. Brak wizji życia w płaszczyźnie etycznej - społecznie pozytywnej. Nieumiejętność wyjścia z trudnej sytuacji, brak wiary w możliwości tego (Grzegorzewska, 1959, s. 33).

W zaprezentowanej definicji zauważa się cechy zachowania określane jako zaburzenia struktury osobowości, które determinują powstawanie niedostosowania społecznego u młodego człowieka. W zależności od płaszczyzny i podejścia danej dyscypliny naukowej do zagadnienia niedostosowania społecznego kształtuje się jego definicja. Podejście socjologiczne do niedostosowania społecznego, scharakteryzowane przez Cz. Czapówa i S. Jedlewskiego, prezentuje osoby niedostosowane społecznie jako tworzące

mniej lub bardziej trwałe reakcje dewiantyczne, wyróżnione nie ze względu na jakikolwiek system społeczny, ale ze względu na system społeczny ujmowany jako element konstelacji systemów społecznych, obejmujących ludzi tworzących zbiorowość współczesnego państwa (Czapów, Jedlewski, 1971, s. 54).

W ujęciu psychologicznym H. Spionek przedstawia ,niedostosowanie społeczne jako zaburzenie sfery emocjonalno-wolowej oraz charakteru i osobowości, czego przyczyną jest powstawanie nieprawidłowych relacji pomiędzy nieletnim a otoczeniem, w którym on przebywa" (Spionek, 1965, s. 275). Autorka odnajduje przyczyny niedostosowania społecznego w błędach wychowawczych oraz niekorzystnych warunkach życia i nauki dziecka. Występujące w rozwoju psychofizycznym trudności wychowawcze prowadzą do objawów wczesnego wykolejenia, przybierających formę aktów sprzecznych z prawem: kradzieży, przemocy, wandalizmu, destrukcji, wypaczeń jednostki, ucieczek z domu, spożywania środków psychoaktywnych. Według A. Makowskiego niedostosowanie społeczne w aspekcie psychologicznym i socjologiczno-pedagogicznym jest

[...] dewiacją osobowościową, spowodowaną czynnikami biopsychicznymi lub środowiskowymi o negatywnym wpływie na kontakty społeczne, aktywność i harmonię życia wewnętrznego jednostki. Zjawisko to uniemożliwia jej konstruktywną socjalizację, efektywną edukację i pomyślną realizację zadań życiowych (Makowski, 1994, s. 25). 
Należy podkreślić, iż pojęcie „niedostosowanie społeczne” jest zależne od obszaru badawczego, płaszczyzny naukowego poznania i ujęcia na tej podstawie definicji dla danego zjawiska. Prezentowany termin ,niedostosowanie społeczne" jest postrzegany z perspektywy pedagogicznej, socjologicznej, psychologicznej w zróżnicowany sposób. Wśród różnych propozycji definicyjnych pojęcia niedostosowania społecznego zauważa się zbieżne stanowiska, iż

społeczne niedostosowanie wyraża się w negatywnym stosunku do norm społecznych, do uznanych społecznie wartości, jest wyrazem trudnej wewnętrznej sytuacji jednostki społecznie niedostosowanej; trudności wychowawcze wynikające ze społecznego niedostosowania cechuje znaczna trwałość postaw aspołecznych oraz jest ogólną postacią (syndromem) zachowania negatywnego wobec norm społecznych (Lipkowski, 1977, s. 106).

W celu wnikliwej analizy pojęcia niedostosowania społecznego wprowadzono podział definicyjny na cztery grupy: definicje objawowe (niedostosowanie społeczne definiuje się jako grupę objawów lub wskaźników o charakterze behawioralnym), definicje teoretyczne (niedostosowanie społeczne w ujęciu teoretycznym, koncentrujące się wokół przystosowania lub prawidłowego funkcjonowania jednostki), definicje operacyjne (niedostosowanie wykazuje się na podstawie symptomów danego zjawiska oraz sposobu jego pomiaru za pomocą narzędzi diagnostycznych), definicje utylitarne (zdroworozsądkowe, administracyjne - prezentujące niedostosowanie społeczne jako formę nieumiejętności wychowania jednostki oraz skupiające uwagę na środowisku, które nie potrafi zaspokoić potrzeb młodego człowieka, w celu pomocy konieczne jest zastosowanie konkretnych metod i środków zapobiegawczych w powstawaniu zaburzenia). W ujęciu prezentowanym przez Ministerstwo Edukacji Narodowej niedostosowanie społeczne wśród dzieci i młodzieży charakteryzuje się poprzez definicje utylitarne, rozróżniając w tym objaśnieniu dwie grupy: niedostosowanych społecznie oraz zagrożonych niedostosowaniem. Wśród osób niedostosowanych społecznie MEN wyróżnia dzieci i młodzież mającą zaburzenia wewnętrzne lub przebywającą w niekorzystnych warunkach środowiskowych, powodujących utrwalone zaburzenia w zachowaniu. Osoby zagrożone niedostosowaniem społecznym to - według definicji ministerialnej - dzieci i młodzież wychowujące się w niesprzyjających warunkach dla rozwoju psychospołecznego, które spotykają się z oddziaływaniem środowiska wychowawczego: rodziny, grupy rówieśniczej i innych, a zachowania zaburzone występują tam sporadycznie. Warto wspomnieć, iż definicja ta jest niedokładna, gdyż niedostosowanie społeczne jako zjawisko różni się częstotliwością i intensywnością objawów (Pytka, 2000). 
Niedostosowanie społeczne jest złożonym i postępującym procesem wśród młodzieży. Sprawą priorytetową jest dostrzeganie osób potrzebujących pomocy i wychwytywanie jednostek podejmujących zachowania ryzykowne oraz zagrożonych niedostosowaniem społecznym. W wyniku weryfikacji i oceny zjawiska niedostosowania społecznego konieczne jest badanie częstości i liczebności występującego zjawiska. Kluczową rolę odgrywa sprawdzanie złożoności procesu niedostosowania społecznego oraz systematyczne badanie zbioru występujących objawów wskazanego zjawiska. Następnie należy - po przeprowadzonych badaniach - usystematyzować uzyskane rezultaty i przedstawić je jako zespół objawów generujących występowanie ,systematycznego zachowania”, które to działania determinują funkcjonowanie jednostki (Pospiszyl, 1978).

Niedostosowanie społeczne jest swego rodzaju skrótem językowym, powstałym w celu wskazania zachowań o charakterze antyspołecznym (Czapów, Jedlewski, 1971). Zachowania młodzieży są związane z nieprzestrzeganiem zasad i norm społecznie istniejących, a tym samym powstawaniem negatywnych reakcji ze strony społeczeństwa. Należy mieć na względzie to, iż każda jednostka ludzka w jakiś sposób przystosowuje się do warunków współcześnie istniejących. Problemem badawczym jest ocena prawidłowości procesu powstałego przystosowania. Myśląc o niedostosowaniu społecznym, konieczne jest postrzeganie tego zjawiska jako obrazu zachowań nieprawidłowo występujących, szkodliwych dla jednostki i niemożliwych do zaakceptowania dla społeczeństwa, w którym ona egzystuje.

\section{PRZYCZYNY NIEDOSTOSOWANIA SPOŁECZNEGO WŚRÓD NIELETNICH}

Narastający proces zmian, nieumiejętność dokonywania ciągłych wyborów i podejmowania decyzji sprzyja rozwojowi osób młodych społecznie niedostosowanych. Stąd biorą się coraz częściej pojawiające się zaburzenia w zachowaniu młodego człowieka, które stanowią podwalinę do powstawania zachowań ryzykownych. Zagadnienie niedostosowania społecznego jest podejmowane zawsze w kontekście relacji między jednostką a środowiskiem. Człowiek powinien przystosować się do środowiska społecznego i kulturowego. Dostosowanie to wiąże się z umiejętnością przestrzegania zasad i norm współcześnie występujących. Zmienność tych społecznych standardów i norm jest zależna od układów społecznych, a także od rodzaju grupy, typu kultury i społeczeństwa, w jakim te zasady występują (Urban, 2008). Funkcjonowanie nieletnich w systemie ludzi dorosłych może generować zaburzenia w zachowaniu. Odmienne poglądy, różnice w postrzeganiu 
rzeczywistości, postęp technologiczny sprzyjają powstawaniu tzw. konfliktu pokoleń, na którego gruncie następuje spotkanie młodego, niedoświadczonego człowieka, szukającego celu i sensu swojego życia z doświadczonym przedstawicielem starszej generacji. Zauważa się, że niedostosowanie społeczne młodzieży jest zjawiskiem coraz częstszym (Pytka, 2000; por. Pierzchała, 2013a; 2013b).

W celu zapobiegania rozwojowi procesu niedostosowania społecznego należy wcześnie rozpoznawać przyczyny wskazanego zjawiska (por. Pierzchała, Cekiera, 2008; 2009). Występowanie zachowań ryzykownych pośród nieletnich jest czynnikiem sprzyjającym postępowaniu niedostosowania społecznego. Wśród przyczyn zachowań ryzykownych upatruje się: zmniejszenie zahamowań, nabranie śmiałości w kontaktach z innymi ludźmi, nawiązanie znajomości, odprężenie się, dobra zabawa, ciekawość, nuda, przekora, „bo inni tak robią”, zwrócenie na siebie uwagi, bunt wobec dorosłych, uległość. Zachowania ryzykowne są powodowane przez: chęć podniesienia poczucia własnej wartości, lęk przed odrzuceniem, ucieczkę od problemów rodzinnych i szkolnych oraz od monotonii, samotność, lęk, poczucie bezsensu życia, pustkę wewnętrzną, pokazanie się jako osoba ważna, ciekawa, wyróżniająca się ponad przeciętność (Róg, 2005). Niewątpliwie zachowania ryzykowne, wielokrotnie powtarzane, przyczyniają się do powstawania niedostosowania społecznego u nieletnich. Niesprzyjające warunki środowiskowe i społeczne generują powstawanie zachowań ryzykownych.

W kwestii rozumienia i zapobiegania zjawisku niedostosowania społecznego konieczne jest rozpoznawanie przyczyn wskazanego zagadnienia. Wśród tych przyczyn wyróżnia się te o charakterze biologicznym i środowiskowym. Do przyczyn biologicznych przyporządkowuje się czynniki organiczne, związane np. z uszkodzeniami centralnego układu nerwowego, jak i czynniki psychiczne, spowodowane dziedzicznością, zintegrowane ze sferą emocjonalną i wolicjonalną. Wśród czynników środowiskowych, czyli przyczyn zewnętrznych, ważne jest funkcjonowanie środowiska rodzinnego w kwestii rozpatrywania znaczenia i wpływu rodzinnego na jednostkę społeczną. Znaczący wpływ wywiera kultura życia rodzinnego, stosunek rodziców do siebie nawzajem i do własnego potomstwa. Niekorzystne oddziaływanie na rozwój osobowości młodzieży mają rodzice dysfunkcyjni, rodziny niepełne, ciężka zarobkowo praca rodziców, także przebywanie nieletniego w atmosferze nieporozumień i konfliktów sprzyja powstawaniu zachowań ryzykownych. Niedostosowanie społeczne młodzieży postępuje w wyniku obcowania z osobami dopuszczającymi się zachowań agresywnych i dewiacyjnych.

Czynniki sprzyjające występowaniu niedostosowania społecznego wśród młodych osób tkwią także w środowisku szkolnym. Do tych czynników można 
zaliczyć nieprawidłowe relacje interpersonalne między uczniem a nauczycielem, niekorzystne relacje między uczniami, a także utrudnienia i opóźnienia w nauce szkolnej (Makowski, 1994). Znaczący wpływ na funkcjonowanie ucznia w otoczeniu klasy ma oddziaływanie nauczyciela, który jest odpowiedzialny za wychowanie i kształcenie młodzieży. Istotne w prawidłowym rozwoju szkolnym są relacje między uczniami, które sprzyjają kształtowaniu się relacji przyjacielskich (Surzykiewicz, 2010). Wspólnie realizowane przez uczniów zadania uczą współpracy i umiejętności kreatywnego rozwiązywania problemów. Odnoszone sukcesy i ponoszone porażki w trakcie procesu kształcenia wpływają na wychowanie młodego człowieka i przyczyniają się do umiejętności radzenia sobie w trudnych sytuacjach (Cichowicz, 1992). Podczas kształtowania się osobowości niepełnoletniej jednostki znaczące jest uzyskiwanie informacji zewnętrznych na temat własnych poczynań oraz nabywanie świadomości znajomości swoich mocnych i słabych stron.

Przyczyn niedostosowania społecznego upatruje się również na płaszczyźnie środowiska społecznego, które jest miejscem akceptacji i wsparcia dla młodego człowieka, szukającego zaspokojenia potrzeby poczucia własnej wartości i bezpieczeństwa. Środowisko społeczne może sprzyjać demoralizacji młodego człowieka - poprzez zachowania destrukcyjne, przestępcze i antyspołeczne. Istotną rolę pełnią rówieśnicy, przyjaciele i znajomi, których nieletni potrzebuje w celu poznania siebie oraz rzeczywistości, w której funkcjonuje (Siemionow, 2011). Umiejętność doboru i tworzenia pozytywnych relacji międzyludzkich sprzyja formowaniu prawidłowej osobowości młodego człowieka. Przynależność do wartościowych grup społecznych przyczynia się do powstawania wśród nieletnich umiejętności dostosowywania się do zastanej rzeczywistości.

\section{OBJAWY I SKUTKI NIEDOSTOSOWANIA SPOŁECZNEGO}

Współcześnie obserwuje się wzrost zachowań ryzykownych u młodzieży w aspekcie rozwoju fizycznego i psychicznego, które mogą przyczyniać się do rozwoju negatywnych zjawisk. Zachowania ryzykowne oddziałują na jednostkę oraz środowisko, w którym ona przebywa. Najczęstsze spośród zachowań ryzykownych to: używanie alkoholu i środków psychotropowych, palenie tytoniu, przedwczesna aktywność seksualna, zachowania agresywne i przestępcze, porzucenie szkoły, ucieczki z domu, stosowanie niebezpiecznych środków w celu poprawienia atrakcyjności fizycznej. Zaprezentowane zachowania są również dostrzegane wśród osób dorosłych, jednak młody organizm ma mniejszą zdolność tolerancji i odporności (Róg, 2005). Nieletni nie nabył 
jeszcze umiejętności prawidłowej oceny obecnej rzeczywistości, rozumienia aktualnie zastanych wydarzeń i zdolności sprawowania kontroli nad swoim postępowaniem. Osoba niepełnoletnia jest narażona na niebezpieczeństwa spowodowane nieznajomością siebie, swoich możliwości, również w kontekście spożywanych środków i podejmowanych decyzji. Człowiek taki nie jest w stanie przewidzieć konsekwencji swoich czynów, a tym samym zapobiegać zachowaniom destrukcyjnym.

Konieczne jest weryfikowanie procesu i etapów niedostosowania społecznego wśród nieletnich oraz wykrywanie symptomów wspomnianego zjawiska, aby skutecznie przeciwdziałać pogłębiającemu się problemowi powstawania zachowań ryzykownych. W celu rozpoznawania i wczesnego diagnozowania niedostosowania społecznego znaczące jest zaznajomienie się z jego charakterystycznymi objawami. Problem niedostosowania społecznego wśród nieletnich zauważa się poprzez występowanie u nich braku akceptacji norm i zasad ogólnie funkcjonujących w danej strukturze społecznej, w wyniku czego powstają zachowania destrukcyjne i społecznie niedopuszczalne. Te nieakceptowalne społecznie zachowania sprzyjają konfliktom między jednostką, która generuje zachowania destrukcyjne, a społeczeństwem, które nie potrafi zaakceptować zachowań deprawujących danego człowieka (Makowski, 1994). Funkcjonowanie jednostki charakteryzuje się nieakceptacją norm, zasad, wymagań i nakazów ujętych w społecznie ustalonych regułach. Nieumiejętność dostosowania się przez nieletnich do norm i zasad obiektywnie istniejących powoduje niszczenie ładu oraz porządku społecznego, a także negatywnie wpływa na mikro- i makrospołeczeństwo (Pytka, 2000). Oddziaływanie młodych osób z perspektywicznego ujęcia niedostosowania społecznego definiuje się jako zespół występujących symptomów, charakterystycznych dla danego zjawiska, do których klasyfikuje się: nadużywanie alkoholu, uzależnienia od leków, toksykomanię, samobójstwa i zamachy samobójcze, prostytucję i promiskuityzm, ucieczki z domu, wagary, pasożytnictwo społeczne, uczestnictwo w gangach podkulturowych. W literaturze przedmiotu można dostrzec rozszerzenie grupy objawów w celu wczesnej weryfikacji niedostosowania społecznego, do których zalicza się: notoryczne kłamstwa, werbalną agresję (wulgarność), lenistwo szkolne, nieprzestrzeganie wewnętrznych zarządzeń i przepisów w szkole, zaburzenia uwagi i koncentracji, lękliwość, konflikty z nauczycielami, rówieśnikami oraz wiele innych (Makowski, 1994). Wszelkie niepokojące objawy należy weryfikować i obserwować, aby pomóc młodemu człowiekowi w ich niwelowaniu i wykształceniu prawidłowych postaw i zachowań społecznie akceptowalnych.

Istnieje pilna potrzeba obserwacji i rozpoznawania stadiów niedostosowania społecznego oraz skutecznego reagowania na zaistniałe zachowania destrukcyjne 
wśród młodzieży. Cz. Czapów wyróżnia i opisuje trzy etapy postępowania wykolejenia społecznego. Stadium pierwsze jest związane z poczuciem odrzucenia. Nieletni w tej fazie zachowuje się w sposób agresywny, antyspołeczny, jego zachowania są nacechowane buntem, negatywizmem, wrogością wobec innych (Strykowska, 2005). Zauważa się u młodych niedostosowanych społecznie nieumiejętność skupiania uwagi i brak motywacji do ukończenia wcześniej rozpoczętej czynności. Stadium drugie charakteryzuje się powtarzaniem, utrwalaniem negatywnych reakcji wobec autorytetów i osób znaczących. Dostrzega się u nieletnich niechęć do relacji z innymi osobami poprzez kontakt emocjonalny oraz odrzucenie bliskich im osób. Następuje odtrącenie relacji społeczno-emocjonalnej z rodzicami i osobami, które dawniej były znaczące dla młodego człowieka (Siemionow, 2011). Nieletni zaczyna zaspokajać swoje potrzeby poza środowiskiem rodzinnym, czego konsekwencją są wagary, używki, niekiedy również wejście na drogę przestępczą. Stadium trzecie wiąże się z rzeczywistym postępowaniem antyspołecznym. Osoba niedostosowana dąży do kontaktu z grupami przestępczymi i czerpie przyjemność z zachowań destrukcyjnych. Jednostka sprzeciwia się normom i zasadom obyczajowym, występując przeciwko przyjętemu, poprawnie funkcjonującemu społeczeństwu - wchodzi na drogę przestępczą (Pytka, 2000).

Niedostosowanie społeczne jest zjawiskiem, które dotyka coraz większej grupy młodych ludzi. W wyniku zaistniałych zmian zauważa się wzrost zachowań ryzykownych, a także tych z pogranicza niedostosowania społecznego. Konieczne jest podejmowanie działań profilaktycznych zapobiegających powstawaniu niedostosowania społecznego. Jednak nie zawsze jest to możliwe, a podejmowane działania pomocowe są nieskuteczne. W wyniku dostrzeżenia objawów niedostosowania społecznego należy zastosować działania pomocowe w celu przeciwdziałania rozwojowi procesu odizolowania i marginalizacji społecznej. Gdy podjęte metody wydają się nieskuteczne, u osoby nieletniej można zaobserwować skutki niedostosowania społecznego. Konsekwencją postępującego niedostosowania społecznego może być wtedy wejście na drogę przestępczą, działania agresywne prowadzone w klikach, gangach czy szajkach. Skutkiem niedostosowania społecznego są zachowania dewiacyjne, ucieczki z domów, wagary, stosowanie środków odurzających, prostytucja, zachowania depresyjne prowadzące do samobójstw. Niedostosowanie społeczne sprzyja powstawaniu wykolejenia i odizolowania, czego konsekwencją jest zatracenie umiejętności funkcjonowania w społeczeństwie. Należy podejmować działania niwelujące zachowania ryzykowne i przejawy niedostosowania społecznego, gdyż skutki tych społecznych zjawisk są zatrważające i oddziałują na całe społeczeństwo. 


\section{DZIAŁANIA PROFILAKTYCZNE}

W celu pomocy i zapobieganiu zjawisku niedostosowania społecznego nieodzowne jest prowadzenie badań z danego zakresu, jak również upowszechnienie działań o charakterze profilaktycznym. W ujęciu H. Radlińskiej profilaktyka to kompensacja jako podstawowy sposób naprawy wykolejenia, zapewnienie tego wszystkiego, co jest niezbędne do normalnego rozwoju fizycznego i kulturowego jednostki i grupy (Zajączkowski, 2001). Cz. Czapów przedstawia pojęcie profilaktyki jako działalności resocjalizującej polegającej na usuwaniu „egzogennych i endogennych determinant aktywności, łamiącej doniosłe normy etyczne, prawne i obyczajowe, które reprezentują interesy szarych struktur społecznych" (Czapów, 1978, s. 67). Ważne jest zapobieganie powstawaniu zjawiska niedostosowania społecznego poprzez zaspokajanie potrzeb oraz tworzenie warunków rodzinnych, szkolnych, środowiskowych sprzyjających prawidłowemu rozwojowi i funkcjonowaniu młodego człowieka. Profilaktyka to szereg działań o charakterze intencjonalnym, mających na celu polepszenie jakości ekonomicznej i funkcjonalnej środowiska rodzinnego, a także działania zmierzające do podnoszenia standardów opieki i pomocy w sytuacji występowania zachowań ryzykownych. Działania profilaktyczne są ukierunkowane szczególnie względem osób, które przejawiają zachowania nieporadności oraz prezentują postawy nieumiejętności radzenia sobie w środowisku (Szymański, 2010). Profilaktyka zajmuje się zarówno zapobieganiem powstawaniu zjawisk niebezpiecznych, niekorzystnych dla rozwoju dojrzałej osobowości, jak również w jej obrębie mieści się usuwanie powstałych skutków nieprawidłowego postępowania człowieka (Strykowska, 2005).

W postępowaniu o charakterze profilaktycznym wyróżnia się profilaktykę pierwszego, drugiego i trzeciego stopnia. Działania profilaktyczne pierwszego stopnia są ukierunkowane na dzieci i młodzież, u których nie zauważa się występowania zachowań ryzykownych. Profilaktyka pierwszorzędowa dotyczy ,promowania zdrowego stylu życia, podnoszenia ogólnego poziomu życia, polepszenia stanu zdrowia, wzrostu poziomu wychowania w szkole i w rodzinie, upowszechnienia form doskonalenia zawodowego, podnoszenia poziomu świadczeń i usług socjalnych, eliminowanie lub opóźnianie zachowań ryzykownych" (Strykowska, 2005, s. 132). Profilaktyka drugiego stopnia jest związana z wykrywaniem i zaprzestaniem podejmowania działań o charakterze niedostosowania społecznego u osób, które prezentują zachowania ryzykowne. Profilaktyka trzeciorzędowa charakteryzuje się ,[...] przeciwdziałaniem procesowi uzależnienia i umożliwieniem powrotu do prawidłowego funkcjonowania jednostki. W celu poprawy jakości funkcjonowania zachęca się osoby do podjęcia rehabilitacji, terapii w celu unikania nawrotom zaburzeń zachowania oraz aby 
podtrzymać uzyskane podczas leczenia rezultaty" (Strykowska, 2005, s. 132). Dopasowanie adekwatnych działań profilaktycznych do potrzeb i sytuacji młodego człowieka sprzyja zmianie zachowania i uformowaniu dojrzałej osobowości.

Działania służące pomocą młodemu człowiekowi w sytuacji jego niedostosowania społecznego są skategoryzowanymi strategiami, skierowanymi na jednostkę, grupę rówieśniczą, rodziców oraz środowisko szkolne. Strategie te obejmują działania o charakterze profilaktycznym za poprzez środki masowego przekazu oraz strategię regulacji prawnej. Formy charakterystyczne dla strategii skierowanej na jednostkę to działania odstraszania, prezentujące skutki podejmowanych zachowań, wychowanie do odpowiedniej konsumpcji, kształtowanie umiejętności interpersonalnych i uczuciowych, proponowanie alternatywnych form aktywności, np. uczestnictwo w zajęciach sportowych, tanecznych, współpraca z grupą, współdziałanie w dyscyplinach drużynowych (Szymański, 2010; por. Pierzchała, 2018). Działania profilaktyczne podejmowane względem rodziców polegają na informowaniu i formowaniu prawidłowych postaw względem zachowań niedostosowania społecznego u młodzieży. Wsparcie rodziców w zakresie profilaktyki zachowań ryzykownych poprzez umiejętności radzenia i postępowania jest kluczowym rozwiązaniem mającym wpływ na wykorzenienie zachowań niepożądanych wśród młodzieży (Róg, 2005). Strategia ukierunkowana na środowisko szkolne przypomina o znaczeniu i funkcji placówek oświatowych w formowaniu osobowości młodych osób. Działania profilaktyczne podejmowanie w obszarze tej strategii wiążą się ze współpracą na płaszczyźnie środowiska lokalnego, wczesnym wykrywaniem nieprawidłowych zachowań, przeciwdziałaniem demoralizacji i deprawacji poprzez współdziałanie wychowawców, pedagogów i psychologów (Makowski, 1994). W celu podejmowania skutecznych działań profilaktycznych konieczne jest uwzględnienie środków masowego przekazu i korzystanie $\mathrm{z}$ dostępnych form telewizyjnych, radiowych, internetowych, poprzez przekazywanie treści edukacyjnych i informacyjnych. Tworzenie plakatów, billboardów czy gazetek, również na terenie szkoły, sprzyja propagowaniu prawidłowych zachowań wśród młodzieży. Regulacje prawne także stanowią skuteczne narzędzie przeciwdziałania niedostosowaniu społecznemu. Należy zaprzestać finansowania kampanii niesprzyjających kreowaniu prawidłowych postaw i zachowań u młodzieży, a przeznaczać środki finansowe na działania o charakterze profilaktycznym (Szymański, 2010).

W celu prowadzenia skutecznych działań profilaktycznych konieczne jest uruchomienie struktur państwowych, ministerialnych i lokalnych. Podejmowane przez władze działania przyniosły efekty w postaci powstałych programów profilaktycznych o charakterze informacyjno-edukacyjnym, afektywnym, 
kompetencji społecznych, także programu działań alternatywnych oraz wczesnej interwencji (Szymański, 2010). Wśród prowadzonych i wdrażanych programów krajowych można wyróżnić: Program Zapobiegania Niedostosowaniu Społecznemu i Przestępczości wśród Dzieci i Młodzieży, Narodowy Program Profilaktyki i Rozwiązywania Problemów Alkoholowych, Krajowy Program Przeciwdziałania Narkomanii czy Krajowy Program Przeciwdziałania Przemocy w Rodzinie. Programy profilaktyczne powstały w celu zapobiegania zjawisku niedostosowania społecznego oraz efektywnemu reagowaniu na pojawianie się zachowań ryzykownych, zwłaszcza wśród młodych osób. Faktem jest, że prawidłowo prowadzona profilaktyka gwarantuje niwelowanie zachowań ryzykownych i zaprzestanie deprawacji młodzieży w problemowym środowisku. Niezbędne jest prowadzenie działań profilaktycznych i wdrażanie nowoczesnych programów wczesnego reagowania, wykrywania i pomagania (Makowski, 1994). Wspomaganie ludzi młodych w rozwoju i kształtowaniu charakteru jest obowiązkiem wychowawczym współczesnego pokolenia, które, by mogło istnieć, potrzebuje dojrzałych i świadomych obowiązku młodych osób pielęgnujących polską tradycję i kulturę.

\section{METODY TWÓRCZEJ RESOCJALIZACJI}

Niedostosowanie jest zjawiskiem społecznym, które dotyka coraz większej liczby osób młodych. Konieczne jest podejmowanie działań mających na celu zapobieganie powstawaniu tego efektu. Kluczowe są działania profilaktyczne, które mają na celu niwelowanie zachowań ryzykownych i niesprzyjających czynników środowiskowych, podejmowanie środków zaradczych skutecznych w formowaniu dojrzałej osobowości. Prawidłowo realizowane działania profilaktycznie przyczyniają się do właściwego rozwoju fizycznego i psychicznego jednostki.

Pomimo różnorodnych form profilaktyki wielu młodych ludzi doświadcza symptomów niedostosowania społecznego. Zjawisko to rozszerza się, powodując negację obowiązujących norm i zasad. Brutalność czynów i brak odpowiedzialności za nie ze strony sprawców rodzi potrzebę tworzenia twórczych form resocjalizacji. Powstają one w celu przywrócenia społeczeństwu młodych, skazanych na marginalizację społeczną, odseparowanych osób. Konieczne jest ukształtowanie wśród młodych niedostosowanych społecznie prawidłowych wzorców zachowań, a także wykorzenienie powstałych zachowań dewiacyjnych. Pomocne w procesie resocjalizacji młodych są metody twórczej resocjalizacji. W koncepcji Cz. Czapówa wychowanie resocjalizujące odbywa się za pośrednictwem kultury, przygotowując młodego człowieka do funkcjonowania w społeczeństwie. Młodzież może korzystać z dóbr kultury poprzez 
uczęszczanie do teatru, kina, oglądanie filmów, słuchanie muzyki. Do metod twórczej resocjalizacji mających na celu pomoc w wychodzeniu z niedostosowania społecznego wykorzystuje się także tworzenie i kreowanie elementów kulturowych poprzez udział w zajęciach artystycznych (Florczykiewicz, 2010). T. Rudowski proponuje arteterapię jako metodę resocjalizującą i pomocową w kwestii wychodzenia z niedostosowania społecznego młodzieży. W założeniu autora celem arteterapii jest eliminowanie zaburzeń poprzez stosowanie środków artystycznych. Poprzez środki twórczej ekspresji młody człowiek przenosi wartości estetyczne do swojej hierarchii wartości, aprobując je jako własne. Nieletni, ubogacony doznaniami artystycznymi, staje się osobą świadomą swojej emocjonalności i uczuciowości, co sprzyja powstawaniu dojrzałej, wrażliwej na ludzką krzywdę osobowości (Florczykiewicz, 2010). W ramach metod twórczych w resocjalizacji osób niedostosowanych społecznie wyróżnia się: procedury dramatyczne, psychodramę, socjodramę, sztuki plastyczne, muzykę (Florczykiewicz, 2010).

W ujęciu M. Konopczyńskiego metody twórczej resocjalizacji służą kształtowaniu prawidłowych zachowań, przemianie tożsamości jednostki i wykorzystaniu potencjału i talentu. Młody człowiek nabywa nowych umiejętności, kompetencji i zdolności do radzenia sobie w zastanej rzeczywistości. Metody twórczej resocjalizacji są prowadzone w formie teatralnej, plastycznej, muzycznej i sportowej. Metoda Teatru Resocjalizującego jest oparta na wydobyciu potencjału twórczego, budowaniu nowej tożsamości i zmiany zachowań osób niedostosowanych społecznie. W trakcie realizacji przedsięwzięć teatralnych następuje wzajemne przenikanie „świata aktorów” i „świata widzów”, a młodzież uczy się także obcowania na scenie, gry aktorskiej oraz umiejętności wyrażania emocji i uczuć poprzez komunikację werbalną i niewerbalną. Celem przedsięwzięcia jest przeżycie danych doświadczeń życiowych ponownie, w sposób prawidłowy, analizując powstałe antyspołeczne zachowanie. Wśród polskich Teatrów Resocjalizacyjnych wyróżnia się Teatr 13 Rzędów i Scena Coda (Konopczyński, 2006).

Metodą twórczej resocjalizacji jest również umiejętność wykorzystania działalności sportowej do wydobycia talentów osób niedostosowanych społecznie. Metoda ta jest skuteczna wobec nieletnich, gdyż sprzyja ruchowi fizycznemu, wysiłkowi, wzmacnia dyscyplinę, pobudza twórcze myślenie, powoduje rozładowanie emocji, napięć, frustracji, mobilizuje do zdrowej rywalizacji, buduje współpracę. Zajęcia sportowe pomagają w kształtowaniu osobowości i tożsamości młodego człowieka, umacniają wśród młodych poczucie przynależności i współdziałania z innymi (Konopczyński, 2006).

Do metod twórczej resocjalizacji zalicza się także muzykoterapię. Zadaniem osoby niedostosowanej społecznie jest słuchanie muzyki, granie na 
instrumentach, wystukiwanie rytmu, taniec i śpiewanie piosenek, również w formie hip-hopu. Efektem stosowania muzykoterapii jest pobudzanie wyobraźni, uspokajanie, tworzenie pozytywnych procesów twórczych czy chociażby przemiana emocji (Kaca, 2014). W trakcie zajęć z zakresu muzykoterapii młody człowiek powraca do trudnych doświadczeń ze swojego życia w celu pobudzenia refleksji i zastanowienia się nad sobą, nad zaistniałymi wydarzeniami oraz przemiany swojego postępowania na akceptowalne społecznie (Konopczyński, 2013).

Metodą terapeutyczną eliminującą napięcia i rozwijającą zdolności są zajęcia plastyczne. Wśród osób niedostosowanych społecznie są one prowadzone w celu pobudzenia wartości estetycznych, umiejętności myślenia twórczego, przekazania uczuć i emocji. Młody człowiek poznaje szeroką gamę barw, kształtów, faktur oraz zapoznaje się ze sposobami twórczego wyrażania siebie za pomocą dostępnych środków plastycznych (Konopczyński, 2013).

Współcześnie dostępne metody twórczej resocjalizacji są bardzo atrakcyjne dla młodych osób. Pozwalają one na wydobycie kwintesencji ich osobowości i wejście w świat emocji, uczuć i wartości w celu poznania siebie, swojej osobowości i tożsamości kulturowej. Umiejętność korzystania z metod twórczej resocjalizacji przez psychologów czy pedagogów i właściwe ich zastosowanie w praktyce sprzyja rozwojowi dojrzałych, świadomych siebie osób.

\section{ZAKOŃCZENIE}

W nieustannym procesie zmian i ciągłego dostosowywania się do zastanej rzeczywistości oraz konieczności podejmowania często trudnych decyzji cenne jest posiadanie przez młodych ludzi umiejętności przystosowywania się. Zdolność ta stanowi istotny czynnik prawidłowego funkcjonowania w społeczeństwie. Prawidłowo uformowana sfera moralna w zakresie ukształtowanej hierarchii wartości sprzyja podejmowaniu właściwych decyzji, zgodnych z normami i zasadami panującymi w danym społeczeństwie. Wartości pełnią w życiu młodego człowieka rolę drogowskazów, wskazują sposób postępowania i pozwalają na dobór metod zmierzających do właściwego zachowania w danej sytuacji. Porządkują też sferę osobową i materialną w aspekcie ważności: od rzeczy najważniejszych do tych najmniej ważnych.

Aby podjąć zachowania pomocowe, konieczne jest rozpoznawanie objawów niedostosowania społecznego po to, aby można było wcześniej zaobserwować zachowania ryzykowne. Decydujące znaczenie ma dostrzeżenie ilości podejmowanych zachowań ryzykownych, na podstawie których stwierdza się skalę 
zjawiska niedostosowania społecznego. Należy pamiętać, że charakterystyczne objawy niedostosowania społecznego są zależne od sfery fizycznej, psychicznej i emocjonalnej jednostki, jak również jej stanu zdrowia. Istotna jest też kwestia środowiska rodzinnego czy szkolnego. Niedostosowanie społeczne przejawia się poprzez zachowania agresywne, wagary, przemoc, zachowania dewiacyjne, uzależnienie od środków odkurzających, przestępczość i inne symptomy. Każde zachowanie krzywdzące podejmowane przez nieletniego powinno być weryfikowane dla dobra jego samego i innych osób.

Zadanie niwelowania zjawiska niedostosowania społecznego nieodzownie wiąże się z podejmowaniem środków profilaktycznych poprzez dostępne metody resocjalizacyjne. Dostępność różnorodnych środków twórczej resocjalizacji przyczynia się do wyrażania osobowości jednostki poprzez taniec, muzykę, sztukę, a także sport. Istotne jest stosowanie środków, które będą odpowiednie dla danej osoby, w zależności od jej osobowości i potrzeb. Przeciwdziałanie powstawaniu niedostosowania społecznego niweluje przyczyny tego zjawiska, jak również sprzyja upowszechnianiu metod pomocowych, gdy dany proces niedostosowania postępuje. Każdy etap rozwoju jednostki zagrożony zachowaniami ryzykownymi bądź niedostosowaniem społecznym wymaga wczesnej interwencji, aby jak najefektywniej wdrożyć czynności pomocowe i pozwolić na kształtowanie prawidłowych zachowań i postaw. Im wcześniej zostaną zastosowane działania profilaktyczne, tym szybszy i skuteczniejszy będzie proces wychodzenia z niedostosowania społecznego.

\section{BIBLIOGRAFIA}

Chudy, W. (2009). Między Werterem a Stawroginem, czyli wartość w życiu człowieka. W: M. Chuda (red.), Filozofia wieczysta w czasach przełomu (s. 133-142). Lublin: Towarzystwo Naukowe KUL.

Cichowicz, J. (1992). Niedostosowanie społeczne dzieci i młodzieży. Wybrane problemy. Olsztyn: Wydawnictwo Wyższej Szkoły Pedagogicznej w Olsztynie.

Czapów, Cz. (1978). Wychowanie resocjalizacyjne. Elementy metodyki i diagnostyki. Warszawa: PWN.

Czapów, Cz., Jedlewski, S. (1971). Pedagogika resocjalizacyjna. Warszawa: PWN.

Florczykiewicz, J. (2010). Twórczość i sztuka w resocjalizacji. Białystok: Wydawnictwo Niepaństwowej Wyższej Szkoły Pedagogicznej w Białymstoku.

Grzegorzewska, M. (1959). Pedagogika specjalna. Warszawa: Wydawnictwo Państwowego Instytutu Pedagogiki Specjalnej.

KACA, P. (2014). Hip-hop jako narzędzie resocjalizacji młodzieży. Gdynia: Wydawnictwo Novae Res. 
Konopczyński, M. (2006). Metody twórczej resocjalizacji: teoria i praktyka wychowawcza. Warszawa: Wydawnictwo Naukowe PWN, Pedagogium.

KonopCZyŃsKi, M. (2013). Kryzys resocjalizacji, czy(li) sukces działań pozornych - refleksje wokót polskiej rzeczywistości resocjalizacyjnej. Warszawa: Wydawnictwo Pedagogium Wyższej Szkoły Nauk Społecznych w Warszawie.

Lipkowski, O. (1977). Pedagogika specjalna. Zarys. Warszawa: PWN.

Makowski, A. (1994). Niedostosowanie społeczne młodzieży i jej resocjalizacja. Warszawa: PWN.

PierzchaŁa, K. (2013a). „Zagrożenie niedostosowaniem społecznym” w odniesieniu do problemów i potrzeb emocjonalnych młodzieży w rodzinie, w grupie rówieśniczej, w szkole. W: J. Izdebska, A. PopŁawska (red.), W trosce o współczesna rodzinę. Teoria, badania, wsparcie. Ujęcie interdyscyplinarne (s. 237-252). Białystok: Niepaństwowa Wyższa Szkoła Pedagogiczna w Białymstoku.

PierzchaŁA, K. (2013b). W poszukiwaniu związków pomiędzy zagrożeniem niedostosowania społecznego młodzieży a jakość życia. W: M. JASIŃSKI (red.), W poszukiwaniu jakości życia. Ujęcia interdyscyplinarne (s. 475-500). Białystok: Niepaństwowa Wyższa Szkoła Pedagogiczna w Białymstoku.

PierzchaŁa, K. (2018). Resocializing Role of Sport and Recreation of Socially Maladjusted People [Resocjalizująca rola sportu i rekreacji osób niedostosowanych społecznie]. W: L. KAtaryńczuk-Mania, M. Przybysz-Zaremba, M. Romeris (red.), Heatlh an Interdisciplinary Study [Zdrowie i badanie interdyscyplinarne (s. 371-386). Lithuania: University in Vilnius.

Pierzchala, K., Cekiera, Cz. (2008). Zwalczanie patologii spolecznych w systemie penitencjarnym Polski i USA. Toruń: Wydawnictwo Adam Marszałek.

Pierzchala, K., Cekiera, Cz. (2009). Człowiek a patologie spoleczne. Toruń: Wydawnictwo Adam Marszałek.

PospiszyL, K. (1978). Niedostosowanie społeczne - przejawy, przyczyny i sposoby terapii. Warszawa: Wydawnictwo Wyższej Szkoły Pedagogiki Specjalnej im. Marii Grzegorzewskiej.

Pytka, L. (2000). Pedagogika resocjalizacyjna. Warszawa: Wydawnictwo Akademii Pedagogiki Specjalnej.

Róg, A. (2005). Profilaktyka niedostosowania społecznego dzieci i młodzieży. W: K. SochA-KoŁodzIEJ, B. ZAJĘCKA (r ed.), Profilaktyka, opieka, wychowanie, resocjalizacja - wybrane aspekty (s. 41-42). Częstochowa: Wydawnictwo Akademii im. Jana Długosza w Częstochowie.

Siemionow, J. (2011). Niedostosowanie społeczne nieletnich: działania, zmiana, efektywność. Warszawa: Wydawnictwo Difin.

SPIONEK, H. (1965). Zaburzenia psychoruchowego rozwoju dziecka. Warszawa: PWN.

STAŃKowski, B. (2018). Efektywność resocjalizacji w salezjańskich Młodzieżowych Ośrodkach Wychowawczych w Polsce. Kraków: Wydawnictwo Naukowe Ignatianum w Krakowie.

Stryкowska, J. (2005). Niedostosowanie społeczne dzieci w wieku szkolnym. Problemy. Diagnoza. Profilaktyka. Gniezno: Wydawnictwo Gnieźnieńskiej Wyższej Szkoły Humanistyczno-Menedżerskiej Milenium.

Surzykiewicz, J. (2010). Agresja i przemoc w szkole. W: Z. Kwieciński, B. Śliwerski (red.), Pedagogika (s. 280-285). Warszawa: Wydawnictwo Naukowe PWN.

SzYMAŃski, A. (2010). Niedostosowanie społeczne dzieci i młodzieży. Wybrane problemy. Warszawa: Wydawnictwo Wyższej Szkoły Pedagogicznej Towarzystwa Wiedzy Powszechnej w Warszawie. 
Urban, B. (2008). Zaburzenia w zachowaniu i niedostosowanie społeczne w świetle współczesnych wyników badań. W: B. URban, J.M. Stanik (red.), Resocjalizacja (t. I, s. 136). Warszawa: Wydawnictwo Naukowe PWN.

Zajączkowski, K. (2001). Profilaktyka zachowań dewiacyjnych dzieci i młodzieży. Toruń: Wydawnictwo Adam Marszałek.

\section{NIEDOSTOSOWANIE SPOŁECZNE NIELETNICH - PRZYCZYNY, SKUTKI, PROFILAKTYKA}

\section{Streszczenie}

W artykule przedstawiono zjawisko niedostosowania społecznego osób nieletnich. Rozpoczynając analizę pojęcia, podkreślono jego złożoność, jak również różnorodność podejść i rozmaitych koncepcji w zależności od płaszczyzny badawczej. Zaprezentowano szereg definicji opisujących niedostosowanie społeczne. Poruszona została problematyka przyczyn niedostosowania społecznego, wynikających z uwarunkowań środowiska rodzinnego, szkolnego i społecznego. Opisano zachowania ryzykowne, które determinują powstawanie niedostosowania społecznego, oraz omówiono objawy niedostosowania społecznego, wraz z etapami wykolejenia społecznego, jak również realne skutki powstałego zjawiska. Zagadnienie profilaktyki i zapobiegania niedostosowaniu społecznemu młodzieży znalazło swoje odzwierciedlenie w treści artykułu poprzez podział działań profilaktycznych, jak i strategie ukierunkowane na pomoc jednostce społecznej. Wskazano też metody i środki twórczej resocjalizacji w celu kształtowania i formowania dojrzałej osobowości u młodego człowieka.

Słowa kluczowe: niedostosowanie społeczne; zachowania ryzykowne.

\section{SOCIAL MALADJUSTMENT OF MINORS \\ - CAUSES, CONSEQUENCES, PREVENTION}

\section{Summary}

The article presents the phenomenon of social maladjustment of minors. When starting the analysis of the concept, its complexity was emphasized, as well as the variety of approaches and various concepts depending on the research level. A number of definitions describing social maladjustment were presented. The issues of social maladjustment resulting from the conditions of the family, school and social environment were discussed. Risky behaviors, which determine the emergence of social maladjustment, are described as well. The article presents the symptoms of social maladjustment with the stages of social derailment, as well as the real effects of the phenomenon. The issue of prevention and social maladjustment preventive treatment of youth has been discussed in the article through the division of preventive actions, as well as strategies aimed at helping the social unit. Methods and means of creative rehabilitation were also indicated in order to shape and form a mature personality in a young person.

Key words: socjal maladjustment; risky behaviour. 